\title{
Estimation of the composition of the forced and free vibrations of the casing of the steel rope roof of Ukraine Cinema \& Concert Hall located in Kharkov over the area of main line tunnel of working metropolitan railway
}

\author{
Valeriy Shmukler ${ }^{1},{ }^{1}$, Valeriy Zhylyakov ${ }^{1}$, and Oleksandr Shapovalov ${ }^{1}$ \\ ${ }^{1}$ O.M. Beketov National University of Urban Economy in Kharkiv, 17, Marshal Bazhanov \\ Street, Khariv, 61002, Ukraine
}

\begin{abstract}
The paper discusses issues related to the dynamic parameters of the metro train influence on the building construction of Ukraine Cinema \& Concert Hall complicated in terms of construction located in Kharkiv City. The hall roof is of peculiar complexity made in the shape of hyperbolic paraboloid hung to the cable roof system and supported by the inclining reinforced concrete arches. Using the equipment by DIAMEX 2000 LLC we have measured vertical and horizontal forced vibrations in the most relevant points of the casing. Natural vibrations were defined by creating dynamic impact of the falling load weighing $10 \mathrm{~kg}$ from a height $\mathrm{og} 2 \mathrm{~m}$. The vibration parameter measurement was carried out by means of Ahat-M vibration analyzer. As a result we have obtained amplitude-frequency characteristics of the forced vibrations caused by metro train movements. The frequency of base and obertones is within $30-50 \mathrm{~Hz}$. At the same time, vibration amplitudes is up 200-350 $\mu \mathrm{m}$. Specific range of vibrations leads to the occurrence of the for framing roof framing (concrete and steel strand guy ropes), noise penetrating into the hall significantly worsens operating characteristics for the spectators. A special calculation of guy rope element taking into account fatigue factors has been made.
\end{abstract}

\section{Structural Design}

Determination of the dynamic load impact on the building constructions is of great importance for estimation of their reliable and safe service during the defined design period. At the same time, it is essential to define nature of the dynamic impact and main parameters of this load (natural and forced vibrations, frequency and amplitude of vibrations, risk of resonance etc.). There is a large number of studies in this direction and methods to calculate dynamic impacts on the building constructions [1-4].

Among these studies the works, a special place stands for the studies that are dedicated to analyse dynamic parameters of the movement of railway transport $[5,6]$, but there are a

\footnotetext{
${ }^{1}$ Corresponding author: $\underline{\mathrm{bk} @ \text { kname.edu.ua }}$
} 
few studies devoted to the impact of metro train traffic on buildings located over and near the tunnels of metro railway. In this case the dynamic load transfer depends on many parameters, in particular, on the thickness of soil layer over the metropolitan, composition and physical and mechanical properties of ground, running tunnel construction arrangement, railing construction etc.

In some cases, the impact of metro train traffic on the building above-ground significantly worsens the operational parameters of these buildings, especially, if this building is classified as a public building. Ukraine Cinema \& Concert Hall located in Kharkiv (Ukraine) built in 1963 belongs precisely to such a construction. At that time there were no analogues of construct of such building in the world's practice. The authors of this project were V.S. Vasyliev, Yu.A. Plaksiiev, V.A. Reusov, design engineer L.B. Fridgan.

The building of Ukraine Cinema \& Concert Hall is distinguished by the originality of construction solution - for the first time in the world's practice the asymmetric scheme of saddle-shaped roof was performed, the casing of $90 \times 48 \mathrm{~m}$ in size was constructed which was closed off with reinforced concrete slabs that was the major achievement of the urban architecture of the second half of the 20th century.

Initially the building design provided the work of hall as a pavilion, however, later building envelope and all required attributes were added to ensure holding concerts and events all year through. In 1980 the building was placed under the protection of the government as a monument of architecture and city development of local significance, protection number 50 .

The façade of Ukraine Cinema \& Concert Hall is shown in Figure 1, the roof plan is shown in Figure 2.

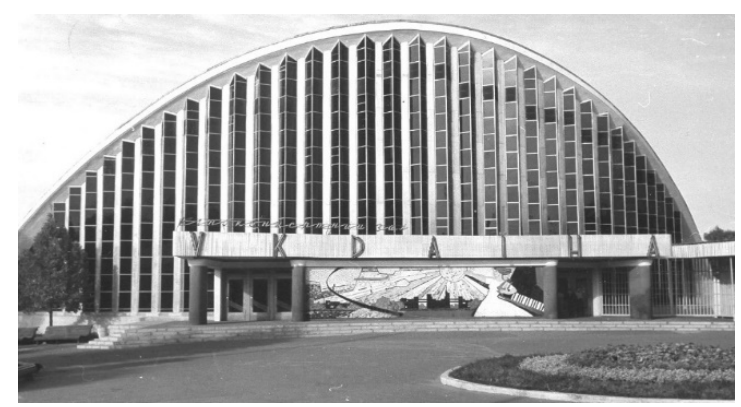

Fig. 1. The front façade of Ukraine Cinema and Concert Hall.

The audience space is designed in the form of one whole amphitheatre with the overall dimensions in plan view of $48.0 \times 45.0 \mathrm{~m}$.

The roof is made in the form of casing outlined in regards to the surface of the hyperbolic paraboloid. The roof is fenced with two parabolic arches with arrows of lift of $31.275 \mathrm{~m}$ and $20.365 \mathrm{~m}$. The angles of inclination of arches to the horizon is 12 (canopy arch) and 45 (steep arch) (Figure 3).

The scheme of the drawing in longitudinal section of the building is shown in Figure 4.

Structural scheme of the hall roof is a casing consisting of reinforced concrete slabs (28 $\mathrm{mm}$ in thickness) suspended to the system of stressed support and shrinking (stabilizing) strands and connected to these slabs of the reinforced concrete plate-casing of $30 \mathrm{~mm}$ in thickness. Combined action of the reinforced concrete slabs (initially serving as a timbering for the reinforced concrete plate) and the plate-casing itself is carried out by means of simultaneous embedding of strands using shotcreting process both in the deepening of reinforced concrete slabs and in the body of the reinforced concrete encasement.

Load due to the roof is taken up by the ferrocement contour of two parabolic arches and transmitted to two foundations. The foundations are located in the arches' crossing point. 


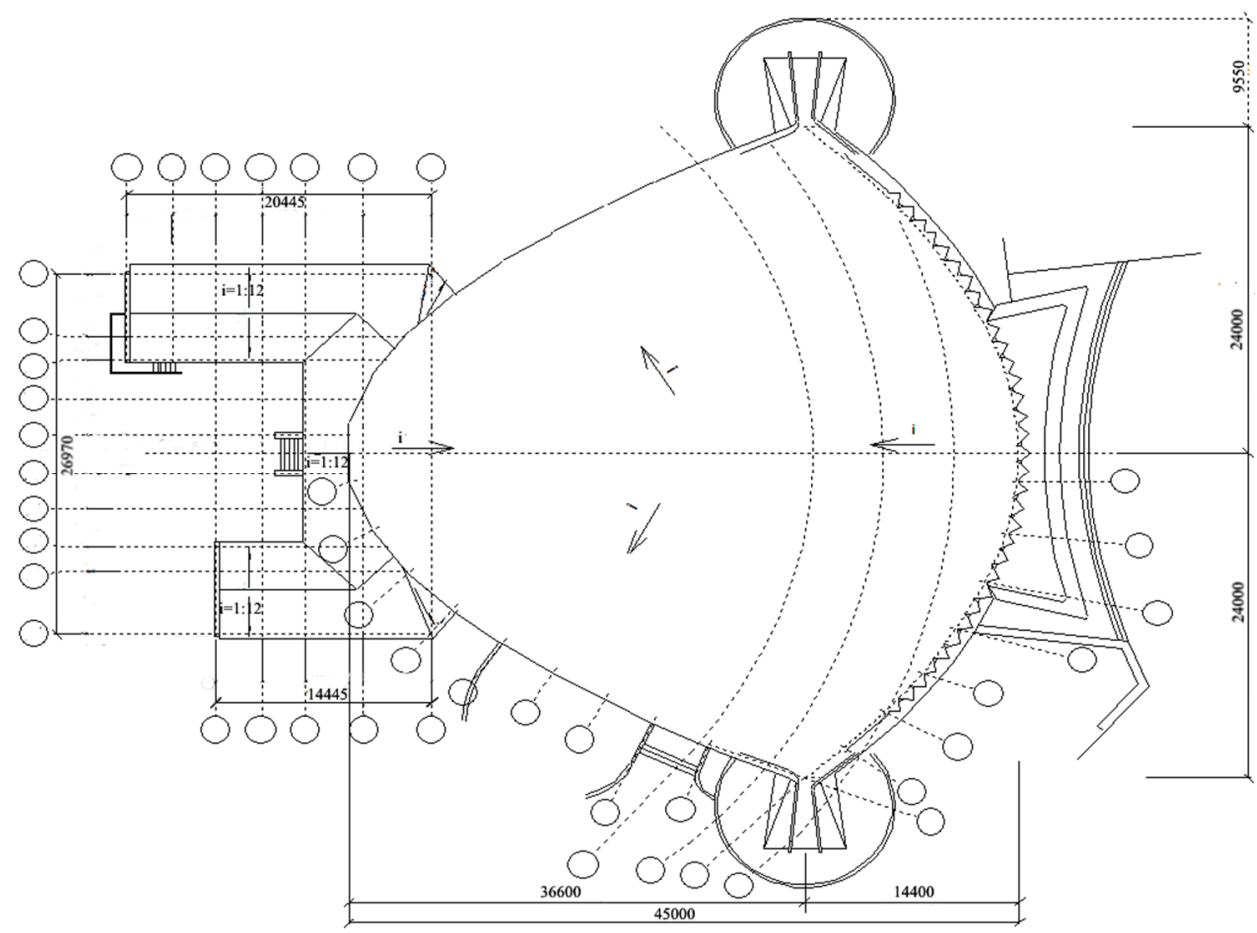

Fig. 2. The roof scheme of Ukraine Cinema and Concert Hall.

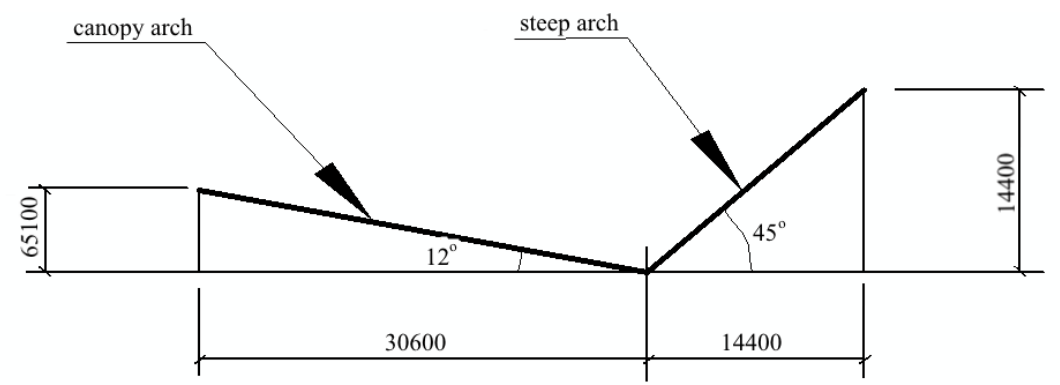

Fig. 3. Geometrical arrangement of the roof arches' incline.

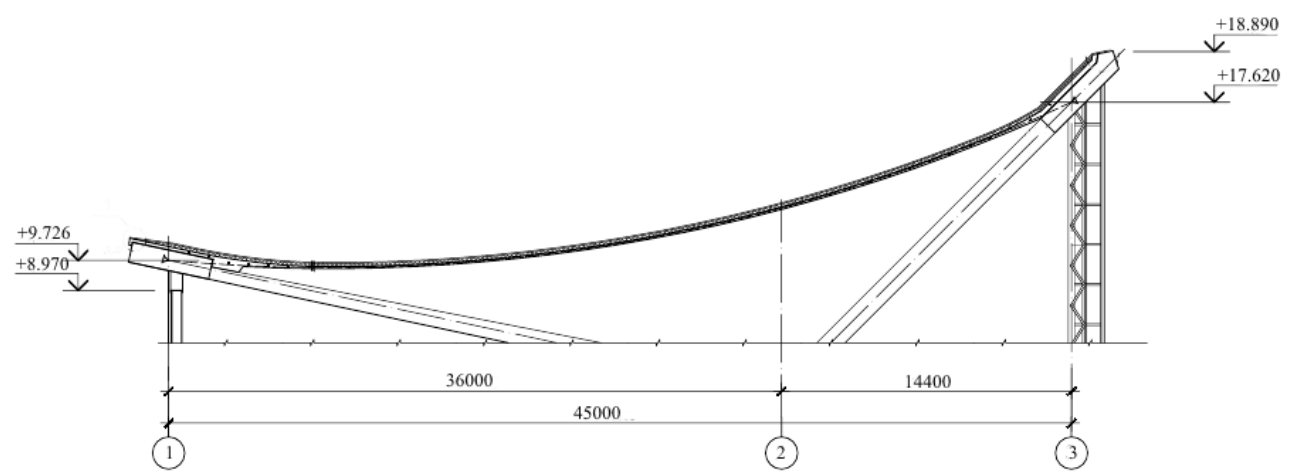

Fig. 4. Scheme of drawing in longitudinal section of the building. 


\section{Dynamical Characteristics}

To define parameters of dynamic impacts on the building construction of Ukraine Cinema and Concert Hall we used equipment manufactured by DIAMEX 2000 and Ahat-M vibration analyser, serial number 1535 .

The main purpose of these measures was to estimate amplitude and frequency components of the forced and free vibrations (absolute vibrations) of supporting elements of the structures of Ukraine Cinema and Concert Hall in the predetermined points. All works were performed in accordance with the standards of Ukraine [6-9].

Analysis of these measurements was carried out using DIAMANT 2 software, version 2.082.13. General layout of the points is shown in the Figure 5.

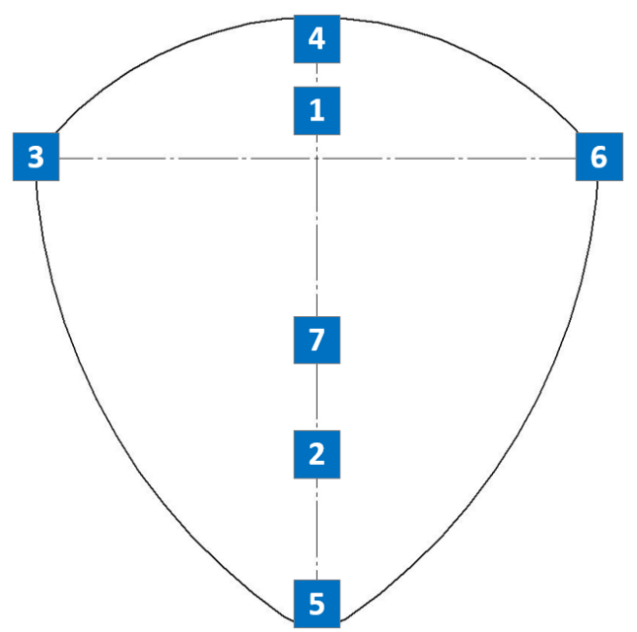

Fig. 5. Location of measurement points to define dynamic characteristics.

Where $1^{\text {st }}$ and $2^{\text {nd }}$ points mean location of control detectors on the supporting floor elements, in the middle part of the hall for spectators; the $3^{\text {rd }}, 4^{\text {th }}, 5^{\text {th }}, 6^{\text {th }}$, and $7^{\text {th }}$ are control points on the support elements of the building roof.

Vibration properties of the constructions were defined in horizontal and vertical directions. The Figure $6 \mathrm{a}, 6 \mathrm{~b}$ shows frequencies and amplitudes of vibrations for the point 1 , the Figures 7 and 8 show frequencies and amplitudes of vibrations for the points 4 and 6 correspondingly.

The analysis of the diagrams showed points to the fact that the frequencies of the forced vibrations in the horizontal and vertical directions in peak points differ by $20-40 \%$, at the same time the frequencies of vibrations in horizontal direction exceed the frequency rate in the vertical direction.

The peak amplitude of the floor vibrations in Ukraine Cinema and Concert Hall is 2.52 $\mu \mathrm{m}$, and the peak amplitude of the vibrations of roof is $0.65 \mu \mathrm{m}$.

The peak frequency of the floor vibration in Ukraine Cinema and Concert Hall is $71.69 \mathrm{~Hz}$, and the peak frequency of the vibrations of roof is $59.76 \mathrm{~Hz}$. 


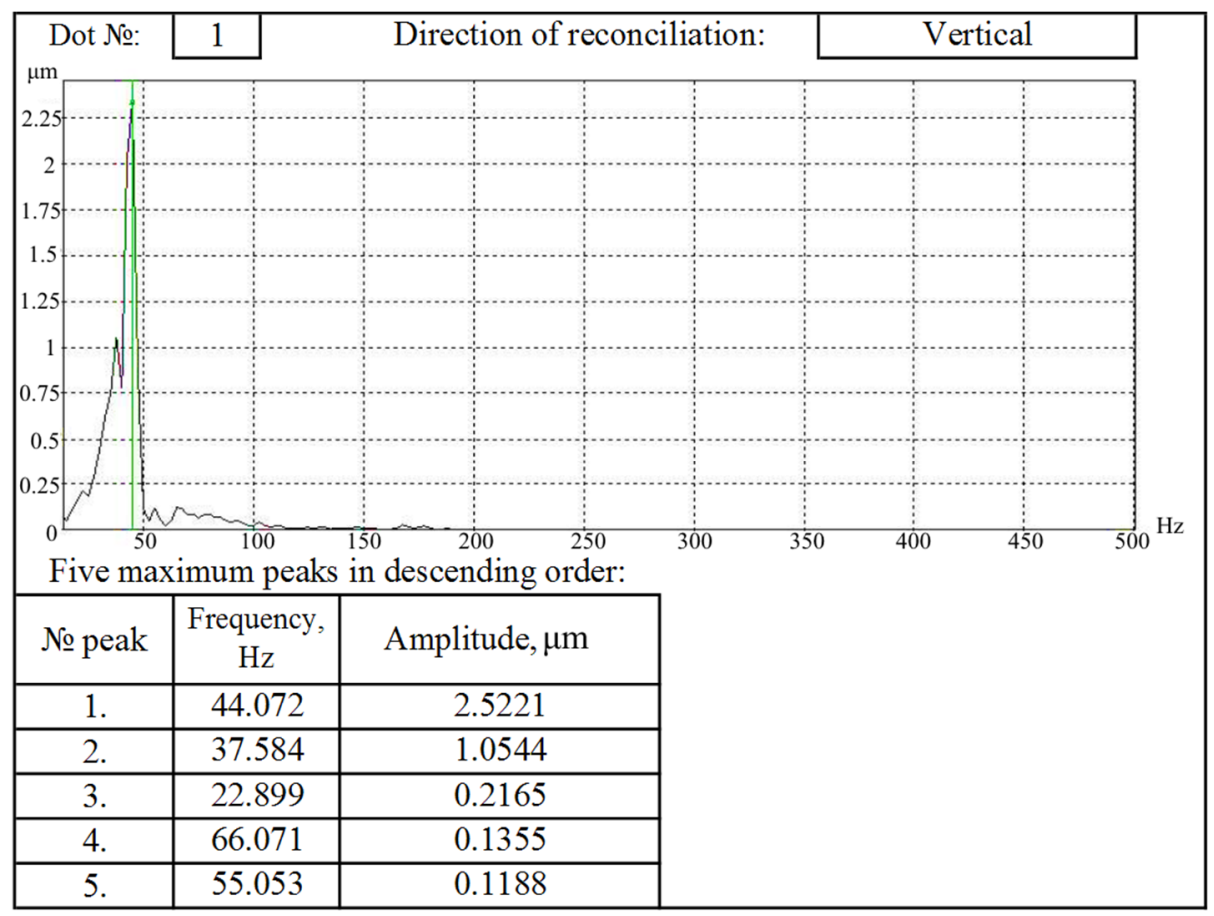

Fig. 6a. Frequencies and Amplitudes of Vibrations for the Point 1

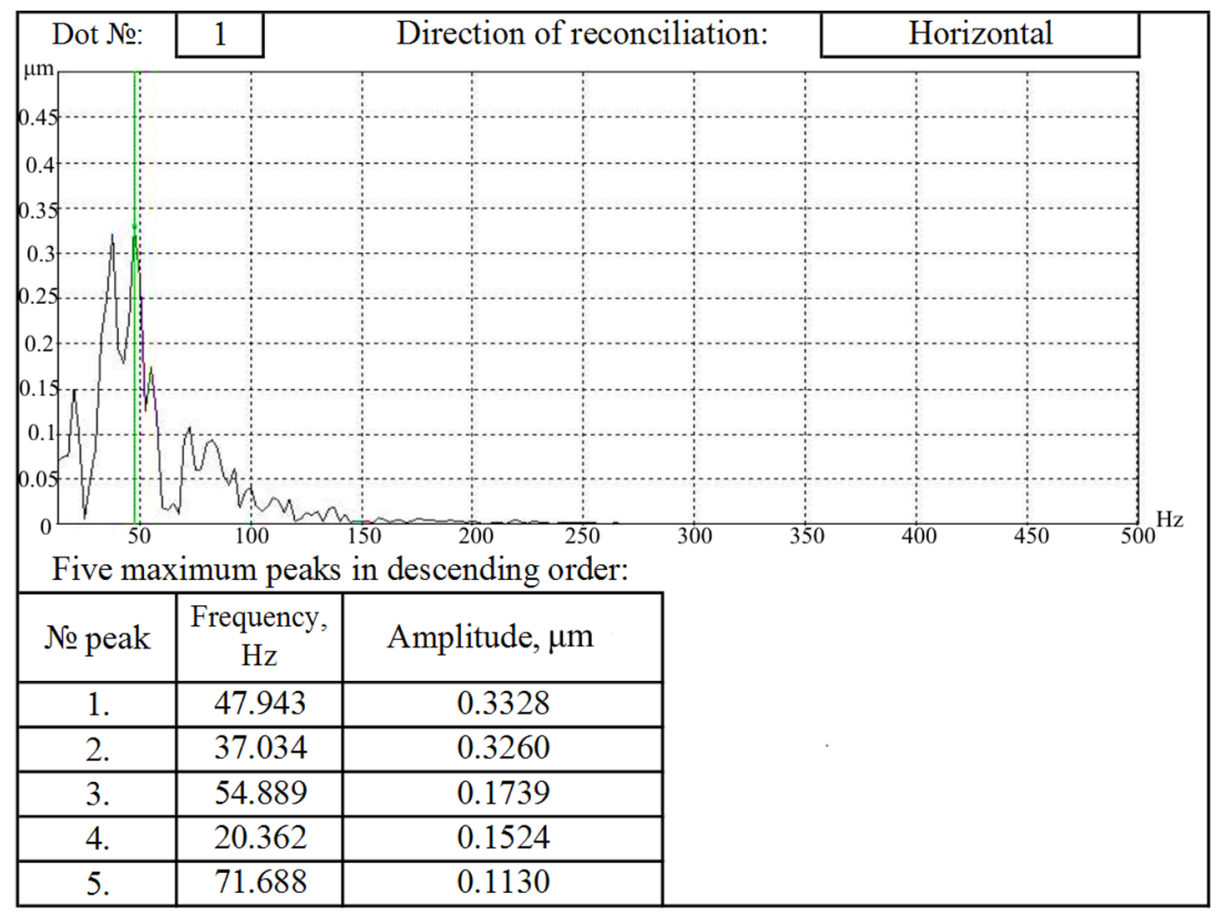

Fig. 6b. Frequencies and Amplitudes of Vibrations for the Point 1. 


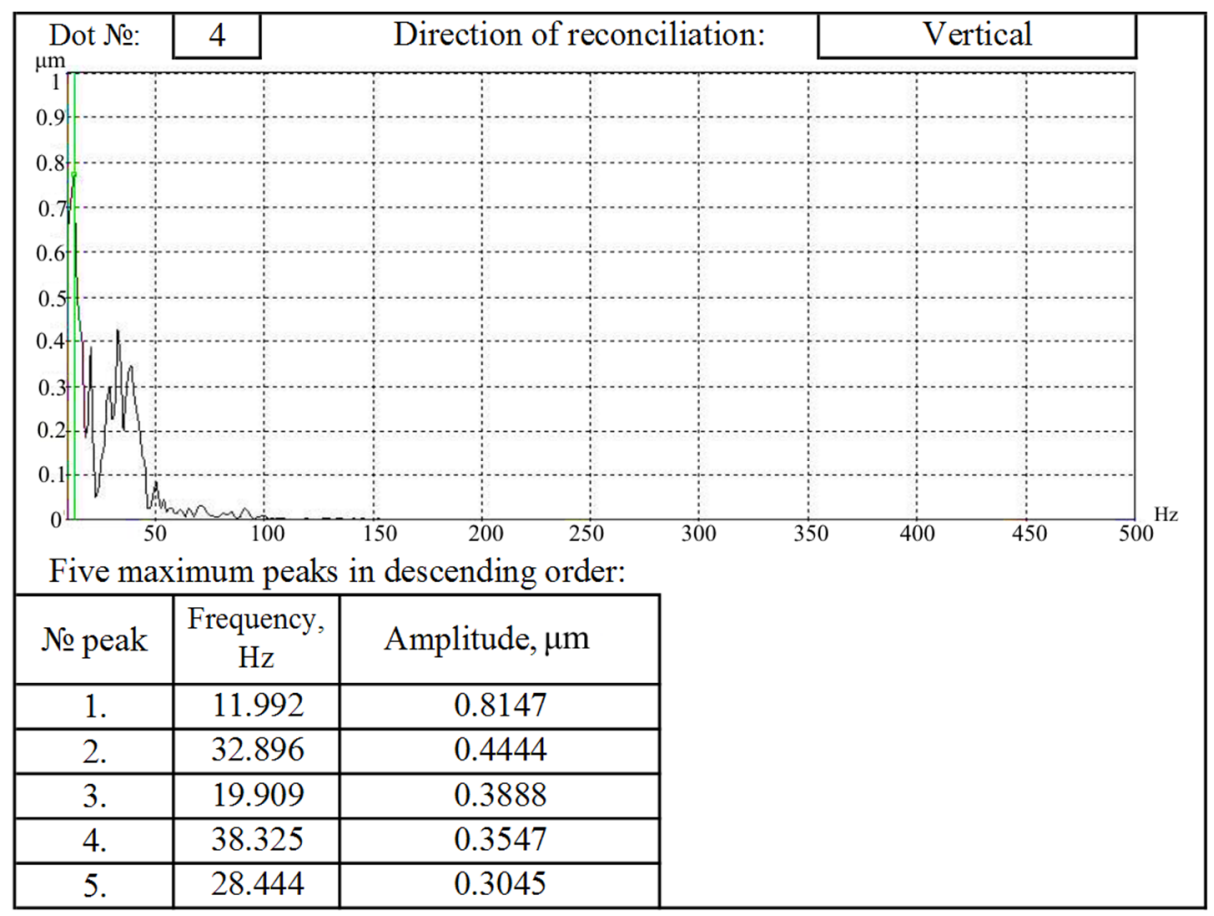

Fig. 7. Frequencies and Amplitudes of Vibrations for the Point 4.

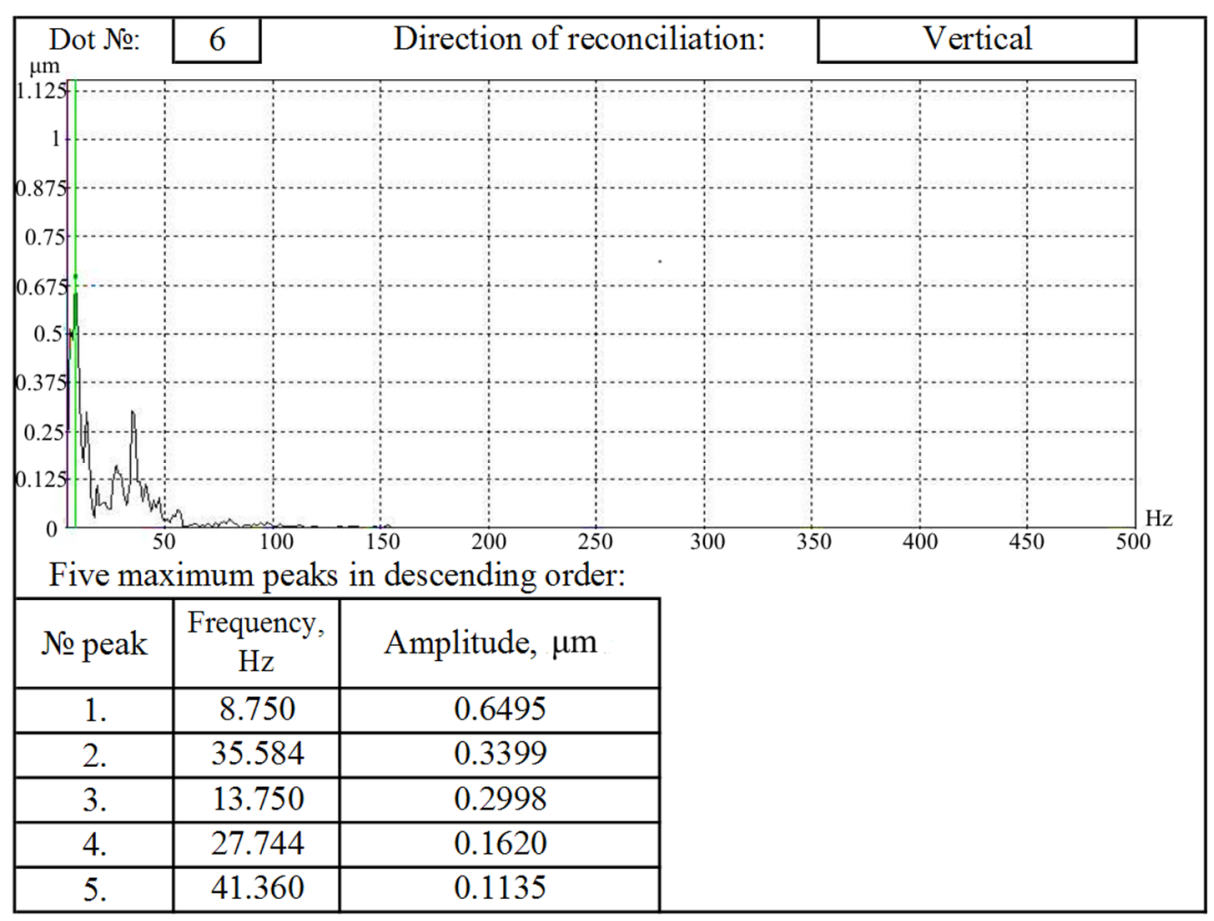

Fig. 8. Frequencies and Amplitudes of Vibrations for the Point 6. 


\section{Stress Calculation in the Roof Guy Ropes}

Approved:

- bay - $48.0 \mathrm{~m}$;

- bending deflection $-5.0 \mathrm{~m}$;

- loads - $0.5 \mathrm{t} / \mathrm{m}^{2}$;

- guy rope (beam) intervals $-1.0 \mathrm{~m}$.

Forcing in guy rope $[1,3]$ is:

$$
N=\sqrt{H^{2}+Q^{2}},
$$

where $H$ - thrust; $Q$ - maximum shearing force.

In this case,

$$
\begin{aligned}
& Q=\frac{q L}{2} ; \\
& H=\frac{q L}{2 \sqrt{6}} \cdot \frac{1}{\sqrt{\frac{L}{l}-1}},
\end{aligned}
$$

where $q$ - shearing load along guy rope $q=$ const; $L$ - length of guy rope; $l$ - bay.

The length of guy rope is defined approximately:

$$
L=l+\frac{D}{2 H^{2}},
$$

where

$$
D=\int_{0}^{L} q(x) M b d x,
$$

$M b$ - girder moment.

Making square area, taking into cons $Q=\frac{q L}{2}$;

$$
\begin{gathered}
M(x)=\frac{q}{2}\left(L x-x^{2}\right) \text { we will obtain: } \\
L=l+\frac{8 \cdot f^{2}}{3 L},
\end{gathered}
$$

where $f$-guy rope bending deflection, when substituting with numeric values, we have:

$$
\begin{gathered}
L \approx 49.4 \mathrm{~m} ; \frac{L}{l} \approx \frac{49.4}{48.0}=1.03 \\
H=\frac{0.5 \cdot 48.0}{2 \sqrt{6}} \cdot \frac{1}{\sqrt{0.03}}=283 \mathrm{kN}
\end{gathered}
$$




$$
\begin{gathered}
Q=\frac{0.5 \cdot 48.0}{2}=120 \mathrm{kN} \\
N=\sqrt{2.3^{2}+12.0^{2}}=307.4 \mathrm{kN}
\end{gathered}
$$

Taking into account the previous stringing ( $3.3 \mathrm{kN}$ under the project) $N \approx 34.0 \mathrm{kN}$.

\subsection{Determination of Wearing Process of Steel Beams}

Using diagram at the page 398 [2] we will obtain that as a result of 55-year operation, the corrosive wear makes up $0.3 \mathrm{~mm}$. Then, the relative wear per one wire ( $\mathrm{F}=5 \mathrm{~mm})$ is equal to $\frac{4.7}{5.0}=0.94$. Taking into account of operation during 50 years as well as considering that the defined relation of the destructive force of wire with corrosion and without it is $\frac{31.93}{34.25}=0.93$. It is taken for the further calculations

$$
\Phi_{\kappa}=0.9 \cdot 5=4.5 \mathrm{~mm}
$$

where $\Phi_{\kappa}$ - diameter of corroded element.

The mentioned above determines definition of stress in guy ropes, taking into account corrosive wear as a middle tension element, according to the formula [2]:

$$
\begin{gathered}
\sigma=\frac{N}{A \cdot K_{A}} \leq R_{y} \cdot \gamma_{c}, \\
\text { where } K_{A}=\frac{t_{k}}{t_{o}}=\frac{4.5}{5.0}=0.9 ; \\
A=16 \cdot \frac{\pi \cdot \Phi_{\kappa}^{2}}{4}=\frac{\pi \cdot 0.45^{2}}{4}=2.545 \mathrm{~cm}^{2},
\end{gathered}
$$

$n=16-$ number of wires in beam.

\section{Conclusion}

The specified range of frequencies determines:

1. Possible accelerated fatigue of materials of roof (concrete and steel guy ropes).

2. Significant noise occurring because of metro train traffic, essentially worsens the set of parameters, determining normal and comfort operation for viewing audience.

\section{Recommendations Related to the Further Building Operation}

1. To ensure substitution of rigid supports of rail tracks with rubber one (dampers) at the area under Ukraine Cinema and Concert Hall building with dimensions mentioned on the scheme equal to the dimensions of building on the scheme. This requirement is caused by a necessity of increase of fatigue failure level of construction (first of all, cable wires) and creation of comfortable atmosphere in the premises during its operation under necessary conditions. 2. To install a roof deformation monitoring system on Ukraine Cinema and Concert Hall building, operating in the on-line mode. 


\section{References}

1. I.A. Birger, Ya.G. Panovko, Prochnost'. Ustoychivost'. Kolebaniya. Spravochnik v trekh tomakh. M. Mashinostroenie, 567, (1968).

2. V.V. Biriulev and others. Proyektirovaniye metallicheskikh konstruktsiy. Spetsyukurs. Ucheb.posobiye dlya vuzov. L.: Stroiizdat, 432, (1990).

3. V.M. Babaiev, S.O. Bugaievskyi, S.M. Evel, I.D. Ievzerov, A.I. Lantukh-Lyashchenko, V.V. Shevetoskyi, O.V. Shymanovskyi, V.S. Shmukler Chysel'ni ta eksperymental'ni metody ratsional'noho proektuvannya ta zvedennya konstruktyvnykh system. K.: Publishing office "Stal", 404, (2017).

4. V.I. Feodosev Soprotivleniye materialov. Publishing Office. "Nauka", M.: 552, (1967).

5. L. Li, M.-X. Zhang, H.-M. Wu. Influence of metro train loading calculation methods on dynamic responses of shield tunnel. Article. July. (2015).

6. I.L. Nikiforova Dynamic Study of Land Surface Movement When Constructing Tunnels. Mining Research and Information Bulletin (scientific and technical journal) 6, (2014).

7. DSTU-NBV.1.2-18:2016 Nastonova shchodo obstezhennya budivel' $i$ sporud dlya vyznachennya ta otsinky yikh tekhnichnoho stanu, Kyiv.: Minenergbud of Ukraine, (2017)

8. DBN B.1.2-14:2009 Zahal'ni pryntsypy zabezpechennya nadiynosti ta konstruktyvnoyi bezpeky budivel', sporud, budivel'nykh konstruktsiy ta osnov, Kyiv. Minenergbud of Ukraine, (2009)

9. DBN B.2.6-98:2009 Konstruktsiyi budynkiv $i$ sporud. Betonni ta zalizobetonni konstruktsiyi. Osnovni polozhennya, Kyiv. Minenergbud of Ukraine, (2011) 